\title{
UPAYA MEWUJUDKAN ALIH TEKNOLOGI MELALUI WARALABA
}

\author{
Slamet Yuswanto \\ BPSDM Kementerian Hukum dan HAM \\ Email : syuswanto2001@yahoo.com
}

\begin{abstract}
Technology is a need for the entire nation, although sometimes the attainment requires significant financial cost. Acquiring technology through the transfer of technology is the necessity for developing countries like Indonesia. Therefore, it needs to be developed through a variety of ways in order to boost economic growth. Many types of transfer of technology, one of the ways is through franchising. The requirements of franchise agreements contained in Government Regulation Number 42 Year 2007 concerning Franchise, particularly in Article 3 which confirms their requirements into a franchise is the registered intellectual property rights. This paper uses normative legal research methods.
\end{abstract}

Keywords: franchise, technology transfer, intellectual property rights

\begin{abstract}
ABSTRAK
Teknologi merupakan kebutuhan seluruh bangsa, walau terkadang untuk memperolehnya membutuhkan biaya yang cukup mahal. Upaya memperoleh teknologi melalui alih teknologi merupakan keniscayaan bagi Negara berkembang seperti Indonesia. Karenanya perlu diupayakan melalui berbagai cara agar dapat mendorong pertumbuhan ekonomi. Banyak ragam terjadinya alih teknologi, salah satu caranya melalui waralaba. Pintu masuk alih teknologi dapat ditemukan dalam persyaratan maupun perjanjian waralaba yang terdapat dalam Peraturan Pemerintah Nomor 42 Tahun 2007 tentang Waralaba, khususnya di dalam Pasal 3 yang menegaskan adanya persyaratan waralaba adalah adanya hak kekayaan intelektual terdaftar. Karya tulis ini menggunakan metode penelitian hukum normatif.
\end{abstract}

Kata Kunci: Waralaba, alih teknologi, hak kekayaan intelektual

\section{Pendahuluan}

Sebagai negara yang mempunyai sumber daya alam melimpah, Indonesia memerlukan teknologi untuk mengolahnya sehingga dapat dimanfaatkan untuk kesejahteraan masyarakat. Berbagai teknologi baik yang sederhana maupun tingkat mutakhir diharapkan mampu mendongkrak pertumbuhan ekonomi. Setidaknya dinyatakan dalam analisa dari
Robert M. Solow melalui penelitiannya di Amerika Serikat, technical change and the aggregate production function pada tahun 1957. Penelitiaan tersebut menyimpulkan bahwa pertumbuhan ekonomi akan dipengaruhi oleh perubahan teknologi sehingga pengembangan teknologi menjadi kunci bagi pembangunan ekonomi jangka panjang. ${ }^{1} \quad$ Karenanya, seluruh negara

\footnotetext{
${ }^{1}$ M. Solow, Robert. (1957). Technical Change and the Aggregate Production Function. Review of
} 
berkembang, tak terkecuali Indonesia, melalui teknologi akan menapak ke babakan baru sebagai negara industrialis dari sebelumnya sebagai negara agraris. Namun, perkembangan teknologi tersebut belum mencapai sasaran yang diinginkan, dalam arti perkembangan teknologi belum dimanfaatkan secara maksimal sehingga belum memperkuat kemampuan Indonesia dalam menghadapi persaingan global. Alasan tersebut paling tidak ditunjukkan oleh World Economic Forum (WEF) bahwa indeks daya saing Indonesia masih di bawah beberapa negara Asean dengan peringkat ke-45 tahun 2018 dari 140 negara. $^{2}$ Oleh sebab itu kebijakan ekonomi dan kebijakan teknologi diupayakan terintegrasi dan diselaraskan untuk meningkatkan daya saing nasional. Peranan teknologi telah menjadi perhatian bangsa Indonesia dalam menjawab permasalahan pembangunan dan meningkatkan pertumbuhan ekonomi guna mencapai masyarakat yang sejahtera, adil dan makmur.

Teknologi diciptakan dengan modal yang cukup banyak. Kelahirannya seringkali didahului dengan penelitian dan pengembangan yang memerlukan waktu dan resiko kegagalan. Oleh sebab itu, ketika menjadi suatu teknologi baru akan

Economic and Statistics, Vol. 39, no. 3 p.320 http://www.jstor.org/stable/1926047 (diakses 23 Maret 2019)

${ }^{2}$ Kompas, 17 September 2018 mempunyai nilai jual yang relatif mahal sehingga bagi negara berkembang harus mengeluarkan modal cukup banyak untuk memperoleh teknologi dari negara maju. Menurut Pasal 1 angka 2 Undang-Undang Nomor 18 Tahun 2002 tentang Sistem Nasional Penelitian, Pengembangan, dan Penerapan Ilmu Pengetahuan dan Teknologi Teknologi, dinyatakan bahwa teknologi adalah cara atau metode serta proses atau produk yang dihasilkan dari penerapan dan pemanfaatan berbagai disiplin ilmu pengetahuan yang menghasilkan nilai bagi pemenuhan kebutuhan, kelangsungan, dan peningkatan mutu kehidupan manusia. Sedangkan World Intellectual Property Organization (WIPO) memberikan definisi teknologi dengan penekanan kepada masalah ekonomi dan industri, bahwa teknologi diartikan sebagai $^{3}$

systematic knowledge for the manufacturer of a product, the application of process or rendering of a service, whether that knowledge be reflected in an invention, an industrial design, a utility model, or a new plant variety, or in technical Information or skills, or in the service and assistance provided by experts for the design, installation, operation or maintenance of an industrial or commercial enterprice or its activities.

Usaha untuk meningkatkan teknologi terus dilakukan agar menghasilkan berbagai produk yang mempunyai daya saing. Salah

\footnotetext{
3 WIPO. (1987). Licensing Guide for Developing Countries. (Geneva: WIPO), p.28
} 
satunya melalui peningkatan kemampuan teknologi sebagaimana tujuan penyelenggaraan penanaman modal yaitu meningkatkan kapasitas dan kemampuan teknologi nasional (Pasal 3 ayat (2) UndangUndang Nomor 25 Tahun 2007 tentang Penanaman Modal). Peningkatan kapasitas dan kemampuan teknologi menggunakan informasi teknologi yang tersedia yang kemudian dipilih dan disesuaikan dengan keperluan sehingga akan mampu menciptakan teknologi baru. Jendela untuk memperoleh teknologi dapat dilakukan dengan memanfaatkan informasi paten baik yang masih mendapat pelindungan hukum maupun yang telah kadaluwarsa. Informasi paten akan menguak berbagai teknologi dari dalam maupun luar negeri melalui invensi yang ada di dalamnya. Invensi adalah ide inventor yang dituangkan ke dalam suatu kegiatan pemecahan masalah yang spesifik di bidang teknologi berupa produk atau proses, atau penyempurnaan dan pengembangan produk atau proses (Pasal 1 angka 2 UndangUndang Nomor 13 Tahun 2016 tentang Paten).

Berbagai invensi sebagai buah dari inovasi teknologi pada saat ini merupakan tolok ukur kemajuan suatu bangsa. Oleh sebab itu, inovasi di bidang teknologi perlu terus diupayakan untuk mengejar ketinggalan dengan Negara maju. Dalam kaitan ini, Kepala Badan Pengkajian dan Penerapan Teknologi (BPPT) mengungkapkan bahwa
Indonesia perlu mengubah paradigma ekonomi berbasis efisiensi (efficiency-driven economy) yang sangat bergantung pada sumber daya asing, menjadi ekonomi berbasis inovasi (innovation-driven economy) yang mengandalkan produk hasil inovasi anak bangsa serta alih teknologi. ${ }^{4}$ Apabila dibandingkan dengan kemajuan di Negara ASEAN, sesuai dengan Global Competitiveness Report 2016-2017, Indonesia masih di bawah Singapura, Malaysia, Thailand. ${ }^{5}$ Meskipun Indonesia memiliki keunggulan dengan jumlah penduduk besar dan tingkat pertumbuhan ekonomi yang tinggi.

Alih teknologi juga merupakan salah satu cara mendapatkan teknologi. Penguasaan teknologi melalui alih teknologi jauh lebih murah dibandingkan dengan membeli teknologi baru. Alih teknologi merupakan implementasi hak Negara berkembang untuk mendapatkan teknologi dari Negara maju. Hal ini dapat dilihat dalam Declaration on the Progressive Development of Principles of Public International Law Relating to A New International Economic Order. Deklarasi tersebut menyatakan bahwa setiap negara memiliki hak untuk mendapatkan manfaat/keuntungan dari ilmu

\footnotetext{
${ }^{4}$ Detik.com, 5 Februari 2018

${ }^{5}$ Schwab, Klaus. (2016). The Global Competitiveness Report 2016-2017", World Economic Forum p. xiii. http://www3.weforum.org/docs/GCR20162017/05FullReport/ TheGlobalCompetitivenessReport20162017 FINAL.pdf (diakses 23 Maret 2019)
} 
pengetahuan dan teknologi khususnya dari negara-negara maju kepada negara-negara berkembang. Adapun di dalam proses alih teknologi terdapat pihak yang terlibat yaitu pemilik teknologi sebagai pihak yang memberi teknologi, Negara pemilik teknologi, penerima teknologi sebagai pihak yang menerima teknologi dan Negara penerima teknologi. ${ }^{6}$

Sarana hukum alih teknologi menurut United Nation Conference on Trade and Development (UNCTAD) terdapat 9 (sembilan) cara yaitu: (1) Foreign Direct Investment; (2) Joint Venture; (3) Licence; (4) Franchise; (5) Management Contracts; (6) Marketing Contracts; (7) Technical Service Contracts; (8) Turn-key Contracts; (9) International Sub-Contracting. ${ }^{7}$

Pelaksanaan alih teknologi pada umumnya dilakukan perjanjian atau kontrak. Menurut United Nations Centre on Transnational Corporation (UNCTC), kontrak alih teknologi meliputi Licensing Agreement/perjanjian lisensi, antara lain paten/hak kekayaan intelektual, know how, franchise dan Technical Assistance/kontrak yang berkaitan dengan bantuan teknik, antara lain: turnkey contract, contracts for

\footnotetext{
6 Declaration on the Progressive Development of Principles of Public International Law Relating to a New International Economic Order.(1987). Journal Article. Vol 54 No.2 (214) Aprile p.317-318. https://www.jstor.org/stable/43786271?newaccount= true\&read-now $=1 \&$ seq $=1 \#$ page scan tab contents (diakses 24 Maret 2019)

7 Putra, Sarsintorini. (2004). Hukum dan Alih teknologi. Makalah, hlm. 7-8
}

providing technical service, design and engineering contracts. ${ }^{8}$

Banyaknya sarana hukum yang bisa digunakan untuk alih teknologi sebagaimana tersebut di atas, penulis hanya akan membahas bagaimana upaya alih teknologi melalui waralaba atau franchise?

\section{Metode Penelitian}

Penulisan karya tulis ini menggunakan metode penelitian hukum normatif dengan pendekatan asas-asas atas beberapa peraturan perundang-undangan di bidang waralaba dan alih teknologi. Mengingat penelitian hukum normatif sehingga data yang digunakan yaitu data sekunder. Sedang bahan hukum yang digunakan antara lain bahan hukum primer berupa Undang-Undang Nomor 18 Tahun 2002 tentang Sistem Nasional Penelitian, Pengembangan, dan Penerapan Ilmu Pengetahuan dan Teknologi, UndangUndang Nomor 13 Tahun 2016 tentang Paten, Undang-Undang Nomor 25 Tahun 2007 tentang Penanaman Modal, UndangUndang Republik Indonesia Nomor 20 tahun 2016 tentang Merek dan Indikasi Geografis, dan Peraturan Pemerintah Nomor 42 Tahun 2007 tentang Waralaba, serta TRIPs. Sedangkan bahan hukum sekunder meliputi

8 UNCTC. (1987). Transnational Corporation and Technology Transfer: Effects and Policy Issues. (New York: United Nations). p.3 
beberapa karya ilmiah yang terkait dengan pembahasan.

\section{Pembahasan}

\section{Konsep alih teknologi}

Globalisasi ekonomi saat ini mengedepankan daya saing suatu negara.

Hal ini merubah pergeseran paradigma pembangunan ekonomi yang tidak mengandalkan banyaknya sumber daya alam, tetapi ditentukan oleh tingkat inovasi teknologi. Inovasi teknologi menjadi semakin multidisipliner, multilateral, dan mahal sementara persaingan pasar meningkat, perusahaan industri dan negara-bangsa merasa tidak mungkin lagi berdiri sendiri dalam inovasi teknologi. Inovasi teknologi dapat terwujud adanya jumlah penelitian dan pengembangan yang bertambah dan diinvestasikan untuk penciptaan teknologi baru. Inovasi teknologi juga dapat diperoleh dengan melakukan transfer pengetahuan dan alih teknologi.

Karena itu, alih teknologi merupakan sasaran strategis bagi peningkatan kemampuan penguasaan teknologi. Melalui aliran teknologi dari Negara maju ke Negara berkembang terjadilah suatu alih teknologi. Pemindahan teknologi tersebut untuk menghasilkan produk maupun proses. Akan tetapi pengalihan teknologi sebaiknya dapat diadaptasi ke dalam lingkungan yang baru, yang kemudian terjadi asimilasi serta inovasi sehingga teknologi asing tersebut mampu diserap menjadi budaya bangsa. Karenanya, L. Zhao dan A. Reisman dalam toward meta research on technology transfer menyatakan bahwa dampak alih teknologi menurut antropolog yaitu adanya perubahan pola budaya masyarakat. Sedangkan sosiolog lebih peduli dengan perannya sebagai kesadaran untuk mengembangkan kapasitas individu dalam masyarakat untuk mengatasi modernisasi dan perubahan yang menyertai alih teknologi. Sudut pandang yang berbeda juga dilakukan oleh para ahli ekonomi dan bisnis. Dikemukakan oleh ekonom E. Mansfield dalam American Economic Review dengan tema East-West technological transfer issues and problems, international technology transfer: Forms, resource requirements, and policies, yang menitik beratkan pada pertumbuhan dan pencapaian tujuan ekonomi sekiranya dilakukan alih teknologi. Sedangkan dari perspektif bisnis dan teknologi, fokus utama dari alih teknologi adalah untuk meningkatkan keunggulan kompetitif perusahaan yang mampu meraih minat pelanggan. Diperkirakan melalui peningkatan keunggulan kompetitif, sebuah perusahaan dan mitranya yang berkolaborasi dalam 
alih teknologi akan mendapatkan keuntungan finansial dan manfaat strategis lainnya. $^{9}$

Dalam terminologi hukum, alih teknologi merupakan sarana untuk mengubah masyarakat dari yang belum mengetahui menjadi mengetahui teknologi terkini, sehingga mampu melakukan penyesuaian atas teknologi yang diserap. Kondisi demikian dikenal dengan law as a tool of sosial engineering (hukum merupakan sarana rekayasa sosial sebagaimana teori Roscoe Pound). Dalam konteks ini peraturan alih teknologi dalam investasi juga menjadi sebuah upaya rekayasa untuk bagaimana terciptanya alih teknologi dari investasi asing di Indonesia. Konsepsi hukum sebagai sarana pembaharuan adalah hukum dalam arti kaidah atau peraturan hukum memang dapat berfungsi sebagai pengatur ke arah kegiatan manusia yang dikehendaki oleh pembangunan atau pembaharuan. Pengaturan alih teknologi dalam investasi di Indonesia bertujuan untuk adanya akselerasi pertumbuhan inovasi dan daya saing ekonomi nasional secara keseluruhan. ${ }^{10}$

\footnotetext{
${ }^{9}$ Ramanathan, $\quad$ K. (2001). E-strategies for technological capability development. (makalah disampaikan dalam Proceedings of the Portland International Conference on Management and Technology, July 29-August 2, 2001 di Portland, US.), p.3

10 Kusumaatmadja, Muchtar. (1976). Hukum, Masyarakat dan Pembinaan Hukum Nasional. (Jakarta: Bina Cipta), hlm.4
}

Pengertian alih teknologi dapat dilihat dalam Pasal 1 angka 11 UndangUndang Nomor 18 Tahun 2002 tentang Sistem Nasional Penelitian, Pengembangan, dan Penerapan Ilmu Pengetahuan dan Teknologi. Dalam undang-undang tersebut dinyatakan bahwa alih teknologi adalah pengalihan kemampuan memanfaatkan dan menguasai ilmu pengetahuan dan teknologi antar lembaga, badan, atau orang, baik yang berada di lingkungan dalam negeri maupun yang berasal dari luar negeri ke dalam negeri dan sebaliknya.

Pemahaman alih teknologi yang hampir sama dengan definisi normatif undang-undang tersebut disampaikan oleh Robert Grose. Secara lebih rinci dinyatakan bahwa alih teknologi adalah proses transfer teknologi dari tempat asalusulnya ke distribusi yang lebih luas di antara lebih banyak orang dan tempat. ${ }^{11}$ Hal ini terjadi di berbagai tempat di antaranya dari universitas hingga bisnis, dari bisnis besar ke yang lebih kecil, dari pemerintah ke bisnis, lintas batas, baik secara formal maupun informal, dan keduanya secara terbuka dan tertutup. Seringkali hal ini terjadi dengan upaya

\footnotetext{
11 Grosse, Robert. (1996). International Technology Transfer in Services. Journal of International Business Studies (1996), p.782 https://www.researchgate.net/ publication/5222745 (diakses 24 Maret 2019)
} 
bersama untuk berbagi keterampilan, pengetahuan, teknologi, metode manufaktur, sampel manufaktur, dan fasilitas di antara pemerintah atau universitas dan lembaga lain untuk memastikan bahwa perkembangan ilmu pengetahuan dan teknologi dapat diakses oleh lebih banyak pengguna yang kemudian dikembangkan dan dimanfaatkan menjadi produk, proses, aplikasi, bahan, atau layanan baru. Alih teknologi tersebut terjadi secara horizontal yaitu alih teknologi dari satu area ke area lainnya atau pergerakan dan penggunaan teknologi yang digunakan di satu tempat/organisasi ke tempat lain. Alih teknologi juga terjadi secara vertikal ketika teknologi dipindahkan dari pusat penelitian terapan ke departemen/ bagian penelitian dan pengembangan atau dari riset dasar ke riset terapan, pengembangan dan produksi.

Adapun model alih teknologi mempunyai banyak ragam sebagaimana dikemukakan oleh berbagai ahli alih teknologi. K. Ramanathan dalam $A n$ Overview of Technology Transfer and Technology Transfer Models, menyuguhkan 4 (empat) model yang mengutip para pencetus model alih teknologi, yaitu: ${ }^{12}$

12 Ramanathan, K. An Overview of Technology Transfer and Technology Transfer Models. the Secretariat of the United Nations Economic and (a) Model Bar-Zakay

Bar-Zakay mengembangkan model alih teknologi berdasarkan pada pendekatan manajemen proyek yang dibagi ke dalam perencanaan, adaptasi, implementasi, dan tahapan perawatan. Kegiatan yang akan dilakukan ditetapkan secara rinci dan memastikan transferor dan transferee mampu memperkirakan teknologi yang dibutuhkan, membuat perencanaan jangka panjang, dan pengumpulan bahan terkait proyek yang menjadi penekanan.

(b) Model Behrman and Wallender

Behrman dan Wallender telah mengusulkan tujuh tahapan untuk transfer teknologi yang mungkin lebih relevan untuk perusahaan multinasional. Tujuh tahapan tersebut yaitu:

- Menyusun proposal dan perencanaan untuk sampai pada keputusan mengenai lokasi dan menyiapkan bisnis termasuk penilaian sumber daya yang baik.

- Memutuskan teknologi desain produk untuk ditransfer.

- Menentukan detail pabrik yang akan dirancang untuk

Social Commission for Asia and the Pacific. p. 811 http://tto.boun.edu.tr/files/1383812118_An\% 20overview\%20of\% 20TT \%20and\%20TT\%20Models.pdf. (diakses 24 Maret 2019) 
menghasilkan produk dan aspek lain yang terkait pembangunan konstruksi dan infrastruktur.

- Pembangunan pabrik dan produksi.

- Mengadaptasi proses dan produk jika diperlukan dan memperkuat sistem produksi agar sesuai dengan kondisi lokal.

- Memperbaiki teknologi produk yang ditransfer menggunakan keterampilan tenaga lokal.

- Memberikan dukungan eksternal untuk memperkuat hubungan antara transferor dan tranferee teknologi.

Salah satu kelemahan dari model ini adalah bahwa selama tiga tahap pertama, transferor mengembangkan proyek alih teknologi dengan sedikit keterlibatan transferee akan memperkuat ketergantungan. Namun, pada tahap kelima dan keenam ada ruang lingkup yang cukup bagi transferee untuk mengasimilasi dan meningkatkan teknologi produk dan proses. Hal ini berarti bahwa alih teknologi tidak berhenti dengan dimulainya produksi.

\section{(c) Model Dahlman and Westphal}

Dahlman dan Westphal mengusulkan model alih teknologi dengan sembilan tahap sebagai berikut:
- Lakukan kelayakan pra-investasi untuk mengumpulkan informasi dan melakukan analisis teknoekonomi untuk membangun kelayakan proyek.

- Melaksanakan identifikasi awal teknologi yang dibutuhkan, berdasarkan studi kelayakan.

- Melaksanakan studi teknik dasar dengan persiapan diagram alur proses, tata letak, keseimbangan material dan energi, spesifikasi desain lainnya, mesin dan inti teknologi yang akan ditransfer.

- Melaksanakan studi teknik terperinci yang melibatkan persiapan teknik sipil yang terperinci termasuk konstruksi dan spesifikasi pemasangan dan identifikasi teknologi periferal yang dibutuhkan untuk membuat efektivitas alih teknologi.

- Melaksanakan pemilihan pemasok untuk peralatan dan layanan sub kontrak untuk membangun pabrik dan merakit mesin serta rencana untuk koordinasi kerja di antara berbagai pihak.

- Mempersiapkan dan melaksanakan rencana pelatihan dan pendidikan dalam konsultasi dengan pemasok teknologi untuk pekerja yang akan dipekerjakan dalam proyek alih teknologi. 
- Bangun pabrik.

- Mulai beroperasi.

- Kembangkan keterampilan pemecahan masalah dan siapkan pengaturan untuk menyelesaikan desain dan operasional masalah yang muncul, terutama selama awal tahun operasi.

Model ini dapat dianggap sebagai perbaikan dari model Behrman dan Wallender dengan penekanan besar pada keterlibatan transferee di semua tahap proyek alih teknologi. Kelemahan utama model ini adalah adanya asumsi bahwa transferee akan memiliki akses ke keahlian teknik tingkat tinggi. Model ini juga sangat sedikit memberi perhatian pada negosiasi dan pascaimplementasi asimilasi.

\section{(d) Model Schlie, Radnor, and Wad}

Schlie, Radnor, and Wad mengusulkan model yang sederhana dengan menggambarkan tujuh elemen yang dapat mempengaruhi perencanaan, implementasi, dan akhirnya keberhasilan alih teknologi. Ketujuh elemen ini tercantum di bawah ini.

- Transferor merupakan entitas yang menjual teknologi kepada transferee.
- Transferee merupakan entitas yang membeli teknologi.

- Adanya teknologi yang sedang ditransfer/dialihkan.

- Mekanisme alih teknologi yang telah dipilih.

- Lingkungan transferor yang dapat mempengaruhi efektivitas proses alih teknologi antara lain meliputi status ekonomi, orientasi bisnis, stabilitas, sikap dan komitmen terhadap proyek alih teknologi, dan kebijakan operasi.

- Lingkungan transferee yang dapat mempengaruhi penyerapan teknologi termasuk infrastruktur fisik dan organisasi, ketersediaan keterampilan, sikap dan komitmen untuk proyek alih teknologi, status teknologi, orientasi bisnis, status ekonomi, dan stabilitas.

- Lingkungan yang lebih besar yaitu sekitar tranferor dan transferee yang terdiri lapisan sub-regional, regional, dan global. Faktor lingkungan yang lebih besar seperti politik hubungan antar negara, nilai tukar, iklim investasi, negosiasi perdagangan, neraca perdagangan, tingkat teknologi, dan status rezim pelindungan kekayaan intelektual dapat berpengaruh besar terhadap keberhasilan proyek alih teknologi. 
Kelemahan dari model ini adalah bahwa ia tidak menawarkan panduan apa yang harus dilakukan seorang transferee.

\section{(e) Model Chantramonklasri}

Lima fase model ini adalah sebagai berikut:

- Melakukan pra investasi dan studi kelayakan

- Mengembangkan spesifikasi dan desain teknik berdasarkan studi kelayakan

- Memulai produksi barang modal berdasarkan spesifikasi dan desain rekayasa yang dimiliki telah dikembangkan.

- Commissioning dan start-up termasuk pemilihan tenaga kerja yang komprehensif.

- Mulai produksi komersial

Kelemahan model ini sama dengan model Dahlman dan Westphal yang menghilangkan elemen negosiasi dan asimilasi. Sedangkan tahapan alih teknologi dapat dijelaskan berdasarkan hasil rumusan konverensi the Role of Intellectual Property Rights in Technology Transfer in the Context of the Convention on Biological Diversity di
Kuala Lumpur, Malaysia pada tanggal 9-20 Februari 2004, yaitu: ${ }^{13}$

\section{1). Pengembangan Teknologi}

Sebagai prasyarat alih teknologi, teknologi perlu dikembangkan. Oleh karena itu penting untuk memasukkan fase pengembangan teknologi ini ke dalam analisis meskipun itu bukan bagian dari alih teknologi yang sebenarnya. Berkaitan dengan pengembangan teknologi, inovasi dan teknologi dibentuk antara lain oleh peraturan perundang-undangan dan peraturan yang mengatur teknologi. Pelindungan yang efektif dari hak kekayaan intelektual yang memadai biasanya diberikan mengingat biaya untuk penelitian dan pengembangan relatif tinggi. Di sisi lain, sejumlah sistem hak milik, sebenarnya dapat menghambat alih teknologi khususnya di negara-negara berkembang. Contoh adanya keterbatasan kapasitas dan sumber daya kantor paten; pemberian paten yang terlalu luas; strategi insentif dalam mengajukan permohonan pelindungan kekayaan intelektual untuk menghalangi penelitian pesaing.

2). Identifikasi terhadap peluang alih teknologi

\footnotetext{
${ }^{13}$ A Technical Study pada the Role of Intellectual Property Rights in Technology Transfer in the Context of the Convention on Biological Diversity, Kuala Lumpur, Malaysia, 9-20 Februari 2004, hlm. 10-11 https://www.cbd.int/doc/meetings/ttc/egttstc02/other/ egttstc-02-oth-techstudy-en.pdf. (diakses 25 Maret 2019)
} 
Identifikasi kebutuhan alih teknologi merupakan tindakan penting dengan melakukan pertukaran informasi. Identifikasi kebutuhan dan peluang alih teknologi melalui akses dan pertukaran informasi yang tepat terkait dengan keberadaan teknologi dan potensi penerapannya, merupakan langkah awal yang penting dalam proses alih teknologi. Dalam hal teknologi yang tidak mudah ditiru, keahlian teknis dan pengetahuan mungkin diperlukan dalam penggunaan teknologi dan adaptasinya. Keberadaan dan desain lembaga yang memadai untuk pengumpulan dan penyebaran informasi di tingkat nasional dan internasional dapat secara substansial menurunkan biaya pencarian teknologi potensial. Database paten nasional dan internasional dapat memainkan peran penting dalam hal ini, dan oleh karena itu merupakan manfaat penting dari sistem kekayaan intelektual selama tahap ini.

3). Alih teknologi yang sebenarnya

Pengaturan untuk melakukan alih teknologi yang sebenarnya terutama teknologi eksklusif, keberadaan hukum menjadi masalah utama dalam tahap ini. Pengaturan dalam melakukan alih teknologi yang sebenarnya sangat penting untuk mengetahui kepemilikan teknologi, dan terutama untuk teknologi yang mudah ditiru. Untuk teknologi seperti itu, keberadaan hukum dan instansi yang berwenang mengatur alih teknologi serta keinginan pemilik teknologi untuk mengamankan teknologinya. Potensi pemasok teknologi dapat dikatakan bersedia secara sukarela mengalihkan teknologinya, khususnya teknologi yang mudah ditiru.

\section{4). Adaptasi Teknologi}

Adaptasi sosio-ekonomi dan budaya lokal terhadap alih teknologi merupakan langkah penting. Terkait dengan teknologi eksklusif, kondisi yang mendasari alih teknologi misalnya, adanya ketentuan yang tercantum dalam perjanjian lisensi. Hal ini mungkin memiliki dampak penting ketika melakukan adaptasi teknologi, dan karena itu sering menjadi penentu keberhasilan atau kegagalan alih teknologi. Selanjutnya, adaptasi yang berhasil mungkin memerlukan penguatan kapasitas penelitian dan pengembangan.

Berkenaan dengan pengembangan teknologi yang terkait dengan alih teknologi tidak hanya terkait peraturan semata. Todung Mulya Lubis dalam alih teknologi antara harapan dan kenyataan $^{14}$ menyatakan beberapa dilema alih teknologi yang dihadapi oleh Negara Dunia Ketiga, antara lain: dilema pertama, teknologi itu bukan sesuatu yang murah. Sejauh mana Negara Dunia Ketiga mampu dan bersedia membayar harga teknologi yang cukup mahal. Sejauh mana Negara Dunia Ketiga memprioritaskannya di

\footnotetext{
${ }^{14}$ Prisma No. 4, April 1987
} 
tengah kebutuhan lain yang mendesak dipenuhi. Parahnya, penentuan harga jual hampir mutlak terletak pada tangan pemilik teknologi. Pembeli hanya diberi pilihan membeli atau tidak sama sekali. Teknologi seringkali dijual secara paket, di mana paket tersebut dengan segala perekatnya (tie-in) secara sepihak sering sengaja dimahalkan. Untuk industri tinggi, pembelian teknologi secara terpisah (partial) hampir mustahil. Dilema kedua adalah pada satu pihak Negara Dunia Ketiga ingin memelihara dan mempertahankan kemerdekaan, tetapi di pihak lain, dengan alih teknologi ini bukan mustahil negara akan melepaskan sebagian kemerdekaan tersebut. Sangat besar kemungkinan, teknologi yang dimasukkan tersebut menimbulkan ketergantungan teknologi (technological dependency). Hal ini tidak sehat bagi perekonomian Negara Dunia Ketiga. Negara Dunia Ketiga sekadar menjadi sandera dari pemasaran teknologi asing. Negara-negara maju dan perusahaan multinasional akan menjadikan kekayaan negara berkembang sebagai sasaran pemasaran teknologinya. Dilema ketiga adalah apabila ketergantungan teknologi ini sudah semakin tinggi, maka kreativitas masyarakat dan anak sekolah akan merosot. Kemalasan untuk bersusah payah pun muncul. Akibat yang paling jelek adalah berkurangnya lapangan pekerjaan sehingga terjadi pemutusan hubungan kerja (PHK) dan meningkatkan angka pengangguran dan kemiskinan. Inilah wajah tidak manusiawi dari alih teknologi.

Selain beberapa dilema tersebut di atas, juga terdapat pertentangan nilai yang tak bisa dihindari dalam alih teknologi sebagaimana dikatakan oleh Denis Goulet bahwa teknologi dianggap sebagai pedang bermata dua, sebagai pengembang di satu sisi, sekaligus penghancur nilai-nilai di sisi lain. Dalam hal ini, alih teknologi dari Barat tentu saja membawa serta nilai-nilai dan pandangan hidup Barat. Nilai pertama adalah rasionalitas. Dalam sudut pandang teknologi Barat, yang dimaksud rasional adalah melihat segala permasalahan dapat dipecah-pecah menjadi bagian-bagian, disusun kembali, dimanipulasi melalui cara-cara praktis, dan diukur dampaknya. Padahal, nilai-nilai tradisional Negara Dunia Ketiga banyak memasukkan aspek-aspek yang tidak mungkin dijawab melalui rasionalitas Barat semacam itu, nilai-nilai tradisional telah melekat dalam kehidupan masyarakat Negara Dunia Ketiga dan dipegang sebagai sebuah kepercayaan. Nilai kedua adalah efisiensi. Efisiensi memiliki keterkaitan erat dengan konsep dari industri yaitu produktivitas. Naik turunnya efisiensi dapat diukur melalui tingkat produktivitas. Produktivitas menilai segala sesuatu dari hasil atau output, dibandingkan dengan input yang diperlukan untuk menghasilkannya. Produktivitas dihitung dari seberapa banyak produk bila 
dibandingkan dengan investasi yang dikeluarkan untuk tenaga kerja, modal, mesin, dan waktu. Nilai ketiga adalah mengutamakan pemecahan masalah secara teknis tanpa memperhatikan aspek alam atau manusiawi. Inginnya segala sesuatu dapat diselesaikan, sehingga tidak memberi waktu terhadap kontemplasi dan harmonisasi dengan alam. Juga mengembangkan perilaku acuh, pasif, dan penolakan terhadap masalahmasalah yang dihadapi. Nilai keempat adalah menganggap kekuatan alam sebagai objek yang harus dipergunakan untuk sebesar-besar kepentingan manusia. Padahal sebagian besar nilai-nilai tradisional sangat mengutamakan hubungan yang harmonis dengan alam untuk menghindari dampak buruk yang dapat ditimbulkan. $^{15}$

Namun demikian, alih teknologi bagi negara berkembang menjadi sebuah keniscayaan yang didukung dengan ketentuan Internasional yaitu Agreement on Trade-Related Aspects of Intellectual Property Rights (TRIPs). Hal ini dapat dipahami mengingat alih teknologi sangat bersinggungan dengan kekayaan intelektual seperti paten dan merek. Pasal 7 dan 8 ayat (2) TRIPs menyatakan pentingnya alih teknologi untuk meningkatkan kesejahteraan sosial dan pertumbuhan ekonomi bagi negara

15 --------(2009). Menelanjangi alih teknologi. Fieldwork in Kutacane, https://nadya.wordpress.com/2009/02/27/menelanj angi-alih-teknologi/ (diakses 25 Maret 2019) anggota khususnya negara berkembang. Pasal 7 TRIPs menyatakan bahwa:

Perlindungan dan penegakan hak kekayaan intelektual harus berkontribusi pada promosi inovasi teknologi dan untuk transfer dan diseminasi teknologi, untuk keuntungan timbal balik dari produsen dan pengguna pengetahuan teknologi dan dengan cara yang kondusif untuk kesejahteraan sosial dan ekonomi, dan untuk keseimbangan hak dan kewajiban.

Sedangkan Pasal 8 ayat (2) TRIPs memberikan penekanan atas kesehatan masyarakat dan gizi (public health and nutrition), bahwa masing-masing negara mempunyai hak untuk mengambil langkahlangkah yang diperlukan dalam menunjang alih teknologi. Pasal 8 ayat (2) menyatakan bahwa:

Langkah-langkah yang tepat, dengan ketentuan bahwa mereka konsisten dengan ketentuan Perjanjian ini, mungkin diperlukan untuk mencegah penyalahgunaan hak kekayaan intelektual oleh pemegang hak atau resor terhadap praktik-praktik yang secara tidak masuk akal menahan perdagangan atau berdampak buruk pada transfer teknologi internasional.

\section{Waralaba: pintu alih teknologi}

Waralaba merupakan salah satu pintu masuk alih teknologi. Peraturan Pemerintah Nomor 42 Tahun 2007 tentang Waralaba menyediakan sarana untuk itu. Di dalam Pasal 3 disebutkan bahwa Waralaba harus memenuhi kriteria sebagai berikut: a. memiliki ciri khas usaha; b. terbukti sudah 
memberikan keuntungan; c. memiliki standar atas pelayanan dan barang dan/atau jasa yang ditawarkan yang dibuat secara tertulis; d. mudah diajarkan dan diaplikasikan; e. adanya dukungan yang berkesinambungan; dan $\mathrm{f}$. Hak Kekayaan Intelektual (HKI) yang telah terdaftar.

Suatu kegiatan usaha dikatakan sebagai waralaba apabila telah mempunyai hak kekayaan intelektual (HKI) yang telah terdaftar. Penjelasan Peraturan Pemerintah Nomor 42 Tahun 2007 tentang HKI terdaftar adalah HKI yang terkait dengan usaha seperti merek dan/atau hak cipta dan/atau paten dan/atau lisensi dan/atau rahasia dagang sudah didaftarkan dan mempunyai sertifikat atau sedang dalam proses pendaftaran di instansi yang berwenang. Hal ini mengandung pengertian, pertama, HKI tersebut sudah mempunyai sertifikat. Jika waralaba menggunakan merek, biasanya merek terdaftar ditandai dengan simbol ${ }^{\circledR}$ atau тм jika merek dari luar negeri. Persyaratan demikian akan memberikan kepastian hukum bagi Pemberi Waralaba maupun Penerima Waralaba mengingat HKI yang digunakan telah mempunyai pelindungan hukum yang diberikan oleh negara melalui Direktorat Jenderal Kekayaan Intelektual (DJKI) Kementerian Hukum dan Hak Asasi Manusia dengan dibuktikan adanya sertifikat. Berbeda dengan HKI yang belum terdaftar atau sedang dalam proses pendaftaran

akan

menimbulkan

ketidakpastian hukum bagi para pihak yaitu Pemberi Waralaba dan terlebih bagi Penerima Waralaba. Ketidakpastian hukum ini akan terbukti saat permohonan merek ditolak sementara Penerima Waralaba sudah menginvestasikan modalnya dengan melakukan perjanjian waralaba dengan Pemberi Waralaba. Demikian juga Pemberi Waralaba harus mengganti merek yang ditolak dengan merek baru dan mengajukan permohonan kembali ke DJKI Kementerian Hukum dan Hak Asasi Manusia. Akibat selanjutnya, Pemberi Waralaba harus mengadakan perjanjian waralaba ulang dengan Penerima Waralaba.

Setelah merek tersebut terdaftar, hak atas merek timbul sejak tanggal pendaftaran sehingga pemilik merek dapat melakukan perbuatan hukum atas merek tersebut berupa pengalihan hak. Pemilik merek sebagai Pemberi Waralaba dapat mengadakan perjanjian lisensi dengan Penerima Waralaba. Perlu diketahui bahwa waralaba merupakan lisensi plus sistem bisnis. Di dalam lisensi terkandung ijin pemanfaatan HKI dengan kompensasi adanya royalti. Sedang sistem bisnis dalam waralaba meliputi pedoman yang menyangkut standar produk, standar periklanan, metode menyiapkan/mengolah produk maupun sistem reservasi. Pemahaman waralaba sebagai lisensi juga diberikan oleh Martin Mandelsohn dalam Franchising: Petunjuk Praktis bagi 
Franchisor dan Franchisee bahwa waralaba adalah: ${ }^{16}$

Pemberian sebuah lisensi oleh seseorang (Pemberi Waralaba) kepada pihak lain (Penerima Waralaba), lisensi tersebut memberi hak kepada Penerima Waralaba untuk berusaha dengan menggunakan merek dagang/nama dagang Pemberi Waralaba, dan untuk menggunakan keseluruhan paket, yang terdiri dari seluruh elemen yang diperlukan untuk membuat seorang yang sebelumnya belum terlatih dalam bisnis, dan untuk menjalankannya dengan bantuan yang terus menerus atas dasar-dasar yang telah ditentukan sebelumnya. Definisi serupa juga diberikan oleh Betsy-Ann Toffler dalam Dictionary of Marketing Terms bahwa waralaba adalah ${ }^{17}$

license granted by a company (the Franchisor) to an individual or firm (the franchisee) to operate a retail, food, or drug outlet where the franchisee agrees to use the franchisor's name, products, services, promotions, selling, distribution, and display methods.

Waralaba merupakan bentuk khusus lisensi. Kekhususan tersebut yaitu adanya keharusan Penerima Waralaba untuk mengikuti metode dan sistem bisnis tertentu dari Pemberi Waralaba yang mencakup prosedur proses produksi barang atau jasa yang diperdagangkan serta manajemen yang

\footnotetext{
16 Widjaja, Gunawan. (2001). Seri Hukum Bisnis Lisensi atau Waralaba, suatu Panduan Praktis. (Jakarta: PT. RajaGrafindo Persada), hlm. 44

17 Ibid, hlm.17-18
}

dimiliki Pemberi Waralaba, sebagaimana rumusan waralaba dari United Nations Centre on Transnational Corporation (UNCTC), Franchise is ${ }^{18}$

a particular form licensing agreement implying a continuing relationship in which the franchisor provide rights usually including the use of trademark or brand name, plus service of technical assistance, training, merchandising and management, in return for certain payment.

Perjanjian lisensi bersifat asesoir (tambahan) atas perjanjian pokok (perjanjian waralaba). Setelah mengadakan perjanjian lisensi, Penerima Waralaba berkewajiban melakukan pencatatan lisensi ke DJKI Kementerian Hukum dan Hak Asasi Manusia. Pasal 42 ayat (5) Undang-Undang Nomor 20 Tahun 2016 tentang Merek dan Indikasi Geografis menyatakan bahwa Perjanjian Lisensi yang tidak dicatatkan tidak berakibat hukum pada pihak ketiga. Artinya bahwa pencatatan lisensi mempunyai akibat hukum bagi pihak ketiga. Ketika Penerima Waralaba meninggal, misalnya, maka ahli waris dapat meneruskan pelaksanaan perjanjian lisensi.

Melalui perjanjian lisensi ini, alih teknologi akan masuk dalam kegiatan usaha waralaba, mengingat lisensi dapat mempercepat proses pengembangan usaha bagi industri dengan menyerahkan sebagian proses produksi melalui teknologi yang

\footnotetext{
${ }^{18}$ UNCTC, ibid, p. 4
} 
dilisensikan serta pemberi dan penerima lisensi dapat melakukan trade off (atau barter) teknologi. ${ }^{19}$ Sedangkan langkahlangkah yang harus dilakukan oleh penerima lisensi antara lain melakukan pemilihan teknologi yaitu telah dibuktikan secara komersial dan tidak ketinggalan zaman dan telah dievaluasi yang berkaitan dengan biaya untuk memperoleh teknologi tersebut serta mampu memilih pemberi lisensi yang sesuai, dengan pertimbangan kedudukan pemberi lisensi dan sumber-sumber alternatif teknologi yang sama dapat diperoleh; mengevaluasi kualitas pengalaman pemberi lisensi dan kemampuan pemberian bantuan teknik yang diperlukan; dan memahami pengalaman pemberi lisensi dalam pemberian lisensinya pada masa lalu. ${ }^{20}$

Sarana hukum alih teknologi juga dapat dilakukan melalui lisensi paten, dengan ketentuan bahwa perjanjian lisensi dilarang memuat ketentuan yang dapat merugikan kepentingan nasional Indonesia atau memuat pembatasan yang menghambat kemampuan bangsa Indonesia dalam melakukan pengalihan, penguasaan, dan pengembangan teknologi (Pasal 78 Undang-Undang Nomor 13 Tahun 2016 tentang Paten). Perjanjian lisensi paten diklasifikasikan atas lisensi

19 Widjaja, Gunawan. (2003). Seri Hukum Bisnis Lisensi (Jakarta: PT. RajaGrafindo Persada), hlm. 15-16

20 Pamuntjak, Amir Dkk. (1944). Sistem Paten, Pedoman Praktik dan Alih Teknologi (Jakarta: Djambatan), hlm. 171 yang bersifat eksklusif dan non eksklusif. Perjanjian Lisensi eksklusif merupakan perjanjian yang hanya diberikan kepada satu penerima Lisensi, dan/atau dalam wilayah tertentu. Sedang perjanjian Lisensi noneksklusif merupakan perjanjian yang dapat diberikan kepada beberapa penerima Lisensi dan/atau dalam beberapa wilayah. (Pasal 76 Undang-Undang Nomor 13 Tahun 2016 tentang Paten dan penjelasannya). Di dalam paten juga dimungkinkan alih teknologi melalui Lisensi wajib. Dinyatakan dalam Pasal 82 ayat (1) Undang-Undang Nomor 13 Tahun 2016 tentang Paten bahwa lisensi wajib dapat diberikan oleh Menteri Hukum dan Hak Asasi Manusia atas dasar permohonan dengan alasan:

a. Pemegang Paten tidak melaksanakan kewajiban untuk membuat produk atau menggunakan proses di Indonesia dalam jangka waktu 36 (tiga puluh enam) bulan setelah diberikan Paten;

b. Paten telah dilaksanakan oleh Pemegang Paten atau penerima Lisensi dalam bentuk dan dengan cara yang merugikan kepentingan masyarakat; atau

c. Paten hasil pengembangan dari Paten yang telah diberikan sebelumnya tidak bisa dilaksanakan tanpa menggunakan Paten pihak lain yang masih dalam pelindungan. 
Namun Permohonan Lisensi wajib sebagaimana dimaksud dalam Pasal 82 ayat (1) huruf c hanya dapat diberikan apabila Paten yang akan dilaksanakan mengandung unsur pembaruan yang lebih maju daripada Paten yang telah ada. (Pasal 83 ayat (3) Undang-Undang Nomor 13 Tahun 2016 tentang Paten).

Paten dapat mendorong alih teknologi. Permohonan paten dari Negara asing merupakan cerminan teknologi kekinian sehingga dapat digunakan untuk mendorong produktivitas pertumbuhan teknologi di Negara penerima, setidaknya bisa memperoleh 50 persen pertumbuhan produktivitas dengan mengimpor teknologi (paten). Dengan demikian 'perdagangan ide' merupakan faktor utama pertumbuhan ekonomi dunia. Selanjutnya paten mencerminkan aliran pengetahuan dan teknologi lintas perbatasan. ${ }^{21}$

Selanjutnya Alih teknologi dalam waralaba melalui perjanjian waralaba yang tercantum dalam Pasal 5 Peraturan Pemerintah Nomor 42 Tahun 2007 tentang Waralaba. Pasal tersebut mengatur tentang persyaratan perjanjian waralaba yang paling sedikit memuat klausula a. nama dan alamat para pihak; b. jenis Hak Kekayaan

21 M. Hoekman Keith E, et al., (2004). Transfer of Technology to Developing Countries. Unilateral and Multilateral Policy Options, p.14, Institute of Behavioral Science, University of Colorado At Boulder. https://www.colorado.edu/ibs/pubs/pec/pec20040003.pdf
Intelektual; c. kegiatan usaha; d. hak dan kewajiban para pihak; e. bantuan, fasilitas, bimbingan operasional, pelatihan dan pemasaran yang diberikan Pemberi Waralaba kepada Penerima Waralaba; f. wilayah usaha; g. jangka waktu perjanjian; h. tata cara pembayaran imbalan; i. kepemilikan, perubahan kepemilikan dan hak ahli waris; $j$. penyelesaian sengketa; dan k. tata cara perpanjangan, pengakhiran dan pemutusan perjanjian. Bimbingan operasional dan pelatihan membuka celah adanya alih teknologi. Waralaba Kentucky Fried Chicken, misalnya, yang didirikan oleh Harland David Sanders (Amerika Serikat) pada tahun 1952, memberikan pelatihan memasak dan menyajikan makanan ayam goreng tepung kepada para Penerima Waralaba agar cita rasanya sama. Demikian juga waralaba Pizza Hut, makanan khas Italia yang didirikan oleh Dan Carney dan Frank Carney pada tahun 1958 yang selanjutnya dibesarkan oleh PepsiCo tahun 1977 hingga meluas ke seantero dunia. ${ }^{22}$ Ketika pelaku usaha Indonesia mendirikan usaha waralaba Pizza Hut, para juru masak akan diberikan pelatihan bagaimana memasak pizza dengan aneka topping. Waralaba kedai digital yang didirikan oleh Saptuari Sugiharto, Yogyakarta telah mempunyai 55 gerai di 35 kota. Waralaba ini bergerak di bisnis

\footnotetext{
${ }^{22}$ Yustisia Serfiyani, Cita, dkk. (2015). Franchise Top Secret Ramuan Sukses Bisnis Waralaba Sepanjang Masa. (Yogyakarta: ANDI), hlm. 211
} 
percetakan yang membutuhkan teknologi dan kemampuan know how bagi yang akan menjadi Penerima Waralaba. Saptuari Sugiharto sebagai Pemberi Waralaba akan memberikan pelatihan bagaimana melakukan pencetakan digital ke dalam berbagai cendera mata yang berupa mug, gelas, kaos dan sebagainya. $^{23}$

\section{Penutup}

Waralaba merupakan pintu masuk alih teknologi. Upaya yang dilakukan dalam waralaba yaitu melalui persyaratan waralaba dan perjanjian waralaba yang terdapat di Pasal 3 dan Pasal 5 Peraturan Pemerintah Nomor 42 Tahun 2007 tentang Waralaba. Salah satu persyaratan waralaba adalah adanya hak kekayaan intelektual terdaftar, dimaksudkan adanya pelindungan hukum atas hak kekayaan intelektual yang digunakan dalam waralaba. Pengertian terdaftar juga adanya pencatatan lisensi hak kekayaan intelektual di dalam waralaba. Alih teknologi dilakukan lisensi dalam waralaba. Selanjutnya melalui perjanjian waralaba, ditentukan adanya bimbingan operasional dan pelatihan. Melalui hal itu, alih teknologi juga dapat dilakukan dalam waralaba.

23 waralaba kedai digital, dapat dilihat di www.youtube.com

\section{DAFTAR PUSTAKA}

\section{Buku dan artikel ilmiah}

Grosse, Robert. (1996). International Technology Transfer in

Services". Journal of International Business

Studies. https://www.researchgate.net/ publication/5222745 (diakses 24 Maret 2019)

Kusumaatmadja, Muchtar. (1976) Hukum, Masyarakat dan Pembinaan Hukum Nasional (Jakarta: Bina Cipta)

Klaus Schwab. (2016). the Global Competitiveness Report 2016-2017", World Economic Forum http://www3.weforum.org/docs/GCR20 16-2017/05FullReport/

TheGlobalCompetitivenessReport2016 -2017_FINAL.pdf. (diakses 23 Maret 2019)

M. Hoekman Keith E, et al., (2004). Transfer of Technology to Developing Countries. Unilateral and Multilateral Policy Options", Institute of Behavioral Science, University of Colorado At Boulder.

https://www.colorado.edu/ibs/pubs/pec/ pec2004-0003.pdf

Putra, Sarsintorini. (2004). Hukum Dan Alih teknologi. Makalah.

Pamuntjak, Amir Dkk. (1994). Sistem Paten, Pedoman Praktik dan Alih Teknologi (Jakarta: Djambatan)

Ramanathan, K, (2001). E-strategies for technological capability development," (makalah disampaikan dalam Proceedings of the Portland International Conference on Management and Technology, July 29August 2, di Portland, US.)

Ramanathan, K. "An Overview of Technology Transfer and Technology 
Transfer Models", the Secretariat of the United Nations Economic and Social Commission for Asia and the Pacific.

http://tto.boun.edu.tr/files/1383812118 An\% 20overview\%20of\% 20TT \%20and\%20TT\%20Models.pdf. (diakses 24 Maret 2019)

Robert M. Solow. (1957). Technical Change and the Aggregate Production Function," Review of Economic and Statistics, Vol. 39, no. 3 (Agustus), http://www.jstor.org/stable/1926047 (diakses 23 Maret 2019)

UNCTC. (1987). Transnational Corporation and Technology Transfer: Effects and Policy Issues, (New York: United Nations)

Widjaja, Gunawan. (2001). Seri Hukum Bisnis Lisensi atau Waralaba, suatu Panduan Praktis. (Jakarta: PT. RajaGrafindo Persada)

Widjaja, Gunawan. (2003). Seri Hukum Bisnis Lisensi (Jakarta: PT. RajaGrafindo Persada,)

WIPO. (1987). Licensing Guide for Developing Countries. (Geneva: WIPO)

Yustisia Serfiyani, Cita, dkk. (2015). Franchise Top Secret Ramuan Sukses Bisnis Waralaba Sepanjang Masa. (Yogyakarta: ANDI)

(1987). Declaration on the Progressive Development of Principles of Public International Law Relating to a New International Economic Order. Journal Article. Vol 54 No.2 (214) Aprile

https://www.jstor.org/stable/43786271? newaccount=true \&read-

now $=1 \&$ seq $=1 \#$

page_scan_tab_contents (diakses 24 Maret 2019)
(2004). A Technical Study pada the Role of Intellectual Property Rights in Technology Transfer in the Context of the Convention on Biological Diversity, Kuala Lumpur, Malaysia, 920 Februari https://www.cbd.int/doc/meetings/ttc/e gttstc-02/other/egttstc-02-othtechstudy-en.pdf. (diakses 25 Maret 2019)

--(2009). "Menelanjangi alih teknologi". Fieldwork in Kutacane, https://nadya.wordpress.com/2009/02/2 7/menelanjangi-alih-teknologi/ waralaba kedai digital, dapat dilihat di www.youtube.com

\section{Peraturan Perundang-Undangan}

Undang-Undang Nomor 13 Tahun 2016 tentang Paten (Lembaran Negara Republik Indonesia Tahun 2016 Nomor 176, Tambahan Lembaran Negara Republik Indonesia Nomor 5922)

Undang-Undang Republik Indonesia Nomor 20 tahun 2016 tentang Merek dan Indikasi Geografis (Lembaran Negara Republik Indonesia Tahun 2016 Nomor 252, Tambahan Lembaran Negara Republik Indonesia Nomor 5953).

Undang-Undang Nomor 25 Tahun 2007 tentang Penanaman Modal (Lembaran Negara Republik Indonesia Tahun 2007 Nomor 67, Tambahan Lembaran Negara Republik Indonesia Nomor 4724).

Undang Nomor 18 Tahun 2002 tentang Sistem Nasional Penelitian, Pengembangan, dan Penerapan Ilmu Pengetahuan dan Teknologi (Lembaran Negara Republik Indonesia Tahun 2002 Nomor 84, Tambahan Lembaran Negara Republik Indonesia Nomor 4219) 
Peraturan Pemerintah Republik Indonesia Nomor 42 tahun 2007 tentang Waralaba (Lembaran Negara Republik Indonesia Tahun 2007 Nomor 90, Tambahan Lembaran Negara Republik Indonesia Nomor 4742).

\section{Media cetak}

Detik.com, 5 Februari 2018

Kompas, 30 September 2016

Prisma No. 4, April 1987 